\title{
'Who Has the Stick Has the Buffalo': Processes of Inclusion and Exclusion on a Pasture in the Indian Himalayas
}

Richard Axelby

\section{OpenEdition}

\section{Journals}

Electronic version

URL: http://journals.openedition.org/samaj/4096

DOI: 10.4000/samaj.4096

ISSN: 1960-6060

Publisher

Association pour la recherche sur l'Asie du Sud (ARAS)

\section{Electronic reference}

Richard Axelby, "'Who Has the Stick Has the Buffalo': Processes of Inclusion and Exclusion on a Pasture in the Indian Himalayas », South Asia Multidisciplinary Academic Journal [Online], 13 | 2016, Online since 08 March 2016, connection on 20 April 2019. URL : http://journals.openedition.org/ samaj/4096 ; DOI : 10.4000/samaj.4096

This text was automatically generated on 20 April 2019.

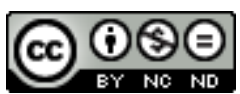

This work is licensed under a Creative Commons Attribution-NonCommercial-NoDerivatives 4.0 International License. 


\title{
'Who Has the Stick Has the Buffalo': Processes of Inclusion and Exclusion on a Pasture in the Indian Himalayas
}

\author{
Richard Axelby
}

\section{Picture a pasture high on a mountain ridge}

1 In the Indian state of Himachal Pradesh, the Dhar Khanda ridge looks down upon the forested slopes and terraced fields of the Chamba valley. Rising to an altitude of 3000 meters above sea level, the ridge is relatively level with two large alpine meadows-Bari Dhar to the East and Lamba Got to the West-divided by a wooded stretch of rough ground. ${ }^{1}$ Though snowbound for much of the year, from late March through to November, the meadows and forests of Dhar Khanda reveal themselves as a grazing space for buffaloes, cows, sheep and goats. These forests and alpine meadows are not only physical domains, but also contested social spaces to which different groups of people compete for access.

2 In formal legal terms all the land along the Dhar Khanda ridge is the property of the state and is managed by the Forest Department of Himachal Pradesh. Access to this particular pasture is supposedly regulated by an official system of 'traditional' rights, permits and quotas. Officially at least, it is the Forest Department that determines who may access and use the resources of Dhar Khanda and who is excluded from them. However, as I go on to show, state authority declines with altitude. This article therefore departs from the narrowly formal official system to consider wider informal access and use arrangement as demonstrated by those groups of Gaddi shepherds and Gujjar buffalo herders who visit Dhar Khanda each summer. 
The difference between property and access is sometimes overlooked in discussions of land-grabs and accumulation by dispossession. Following Ribot and Peluso's (2003) distinction between 'property' and 'access' this article explores the area between that which people have property rights to, and that which they are able to extract benefit from. In parallel to this, Sikor and Lund (2009) identify a second 'grey zone' existing between power and authority where decisions about the distribution of resources are legitimised. Taking as its subject the multiple ways that these two sets of relationships play out on the Dhar Khanda ridge, I consider their construction and discursive constitution. Like the other papers in this special issue, this article examines the techniques used by those seeking to appropriate land in South Asia. In it I show how discourses of indigeneity and belonging are used to justify and resist competing claims not just to resource ownership (property) but also to the ability to benefit from resources (access). Examining the politics of natural resource use in this way brings to the fore inequalities in access and explains the ways in which they occur.

Figure 1:

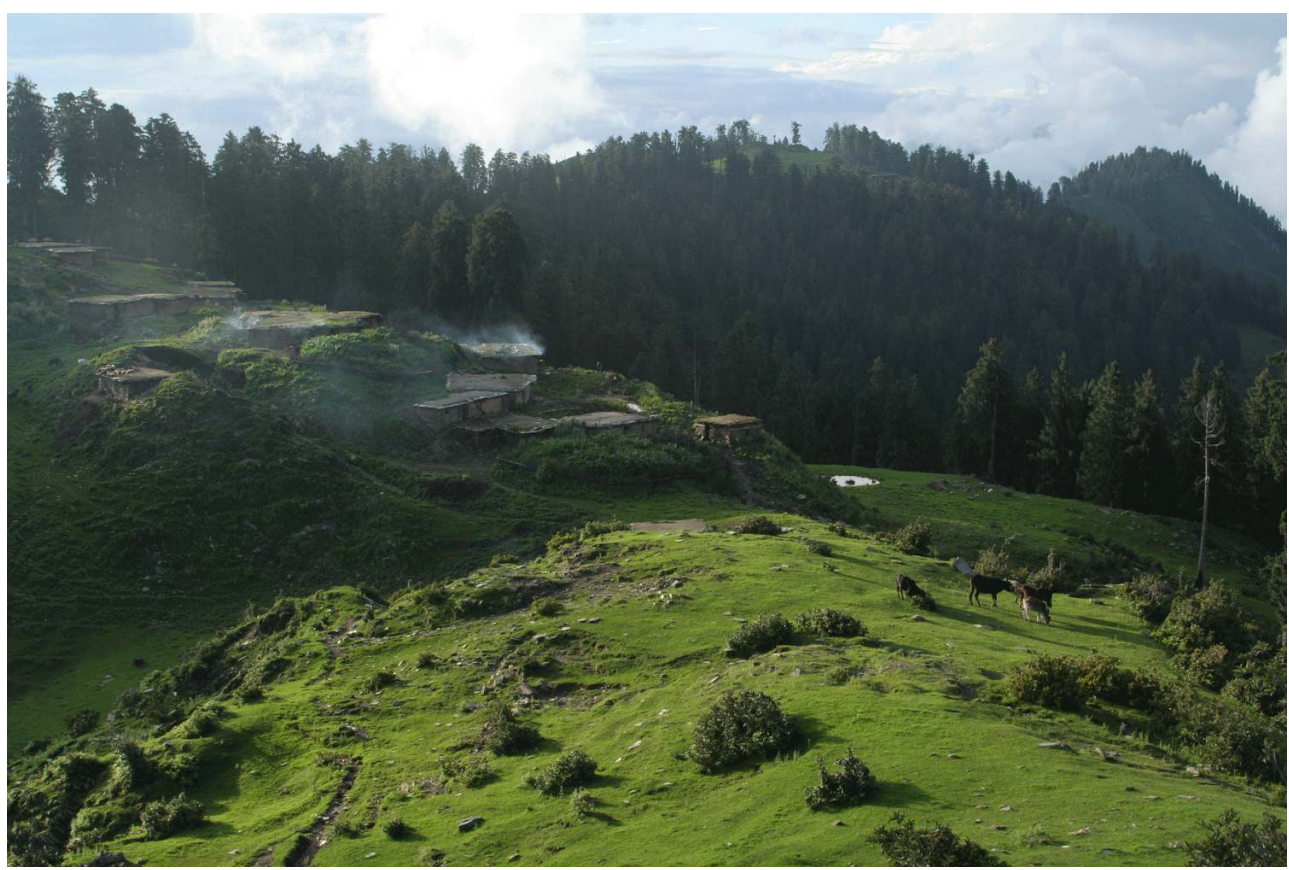

THE DHAR KHANDA RIDgE WITH LAMBA GOT IN THE FOREgROUND AND BARI DHAR IN THE DISTANCE (PHOTO: AUTHOR'S OWN)

\section{Pastoralism and property in the western Himalayas}

The geography of the western Himalayas provides an ecological niche ideally suited to the practice of mountain pastoralism. ${ }^{2}$ Central to the coordination of temporal and spatial mobility are complex sets of access arrangements: nomadism in the western Himalayas requires the navigation of human landscapes as much as physical ones. One method by which the necessary flexibility of movement is achieved is through the collective holding of pasture resources as a form of common property (Sandford 1983, Scoones 1995). The literature on migratory pastoralists in the western Himalayas has focused attention on 
the existence and workings of these grazing commons and, in particular, on the negative impact that the modern state has upon them.

The historical practice of pastoral nomadism in the Kashmir and Punjab Himalayas has been examined by Singh $(1998,2009)$, Bhattacharya $(1986,1995)$ and Chakravarty-Kaul $(1996,1997)$. Traditional access to grazing is characterised as having been regulated through flexible combinations of collective and segmented property arrangements (Singh 1998). However, the arrival of British rule in the mid $-19^{\text {th }}$ century marked the beginning of an existential challenge to long-standing arrangements of shared resource ownership and management. Bhattacharya describes the colonial state as having sought to 'redefine the temporal rhythms of pastoral activity' (1995: 57). Through the latter half of the $19^{\text {th }}$ century, 'the gaddis and gujars of the hills.... found their access to forests closed, their rights redefined, the rhythms of their movements controlled, their spatial movement restricted' (Bhattacharya 1995: 54). Land settlement saw grazing land internalised under village management while other 'wastes' were brought under direct government control (Singh 2009: 76). The micro-management of forest resources and the introduction of an official system of grazing permits, taxes and quotas restricted what had previously been fluid and flexible customary arrangements (Dangwal 2009). Post-Independence successive governments continued to prioritise settled agriculture over mobile pastoralism (Saberwal 1999, Chakravarty-Kaul 1996). With the timing and route of migration severely constrained, 'pastoralists were frozen in their tracks' (Chakravarty-Kaul 1997: 134).

These accounts of historical change consider what happens when 'traditional' shared forms of resource ownership and management collide with bureaucratic administration and 'modern' systems of private and state property. As such they successfully focus attention on the historical and contemporary processes of expropriation, dispossession, alienation and forcible exclusion that have been inflicted on pastoralists and other forestdependent populations over the last two centuries. However, while recognising considerable upheaval in the way natural resources are formally governed it is also apparent that across much of the western Himalayas nomadic pastoralism remains a viable economic activity. Exploring alternative conceptualisations and configurations of state, community and property, it is possible to look beyond sweeping processes of macro change to bring out the details of contemporary resource use.

7 Previously I have compared the proposition that the modern state has critically undermined common property resource management arrangements against the example of a group of shepherds as they negotiated access to grazing (Axelby 2007). Following these shepherds through the course of their migration cycle I revealed the dynamic interactions of individuals, communities and the agents of the state through which officially recorded property regimes are creatively reinterpreted. While that earlier article celebrated the ability of migratory shepherds to obtain grazing in the face of official attempts to restrict their movement, this article probes deeper into questions of access, authority, legitimacy and ultimately power. Focussing on a single pasture with multiple users, here I expose a less optimistic picture which highlights the hierarchies existing within and between nomadic groups. By revealing who gains benefit from the pasture and how they do so, it provides a window on the ways that interests are negotiated, mediated and contested. Updating the macro changes in property regimes that swept India in the $19^{\text {th }}$ century, this paper shares with the others in this special issue a focus on new processes of accumulation and new forms of access and exclusion that are taking place across 21st century South Asia. 


\section{Access to grazing resources part 1: inclusion, cooperation and community}

\section{The shepherds arrive in the Saal valley}

8 As the snow melts from Dhar Khanda, Gaddi shepherds leave their winter grazing grounds in Punjab and turn their flocks north. Those from the Saal valley aim to arrive back in their village homes in mid-April. Gaddi people live on either side of the Dhaula Dhar mountain range which separates Kangra from Chamba District, but they trace their origins to the upper part of the Chamba Valley known as Gadderan. Though Gaddis are well-known as nomadic shepherds, the majority of Gaddi households do not keep migratory flocks and from those families that do only one or two men will actually travel with them year round. Gaddi agro-pastoralism typically involves the combination of subsistence farming (typically a summer maize crop and wheat in winter) and migratory shepherding (flocks of sheep and goats provide a cash income from the sale of meat and wool). In recent decades the availability of new occupations-locally in government or private service; further afield typically labouring or in tourism-has increasingly provided Gaddi families with alternatives to shepherding. However, rises in the demand for, and price of, goat meat means shepherding remains a profitable occupation (Axelby 2005). After a few weeks grazing in village pastures, farmers' fields and forests close to the river Saal the flocks of sheep and goats move on to higher pastures around the Dhar Khanda ridge. Dhar Khanda is close enough to spend time at home (it's possible to make a return visit in a day) but with grazing sufficient for a stay of several weeks.

On my first visit to Dhar Khanda in May 2002, I found a group of shepherds had established camp on the meadow at Bari Dhar. Prithu ${ }^{3}$ was caring for the new-born lambs while the adult sheep and goats were grazing in the forest below. Prithu explained he travelled with four other shepherds: the hired hands (chotepuhal) Mohinder and Dimu were with the flock in the forest while the permit holders Deso and Bir spent a few days at their nearby homes. While Prithu and his groups enjoyed their stay at Bari Dhar, two other groups of Gaddi shepherds took up temporary residence at Lamba Got. Dharam Chand was one of the older and cannier of the Saal valley shepherds and his opinion carried some weight with the others. Sharing Lamba Got with Dharam Chand's group was a small flock belonging to Harilal and Monnu, an uncle-and-nephew team from the nearby village of Chaghan. None of the above described groups of shepherds have ever had an 'official', permanent or specific right to graze their animals in the Dhar Khanda forests. They are able to do so because Forest Department officials recognise the need for flocks to spend some time around this area while travelling between their summer and winter grazing grounds. The claims made by these shepherds were based on their own long-term usage (i.e. over several generations) and the proximity of their home villages. According to Deso:

When we settle in one place then others won't come even though there is no permit [legal right] for that place. Going to the same place every year becomes tradition and others won't use it if they know that someone else is already established there. An understanding exists about who stays where and that they shouldn't be disturbed. ${ }^{4}$ 
10 From late April to the end of May these flocks grazed freely over the meadows and surrounding forested slopes. Sharing common residence in the Saal valley, the shepherds were well known to each other and travelled throughout the year along a similar migration path. ${ }^{5}$ Relationships were commonly expressed in kinship terms; they would eat and drink at one another's camps and provide cover for one another allowing time to be spent at home. This confirms Agrawal's view of 'communities on the move' as a defining feature of nomadism (1999). Prithu was not alone in commenting that working and travelling together with others 'gives security': where necessary they would club together and support one another in the face of external challenge. As we shall see, in 2002 the security provided by numbers was an important resource.

11 Occupying the mid-point of the Bari Dhar meadow are four large, flat-roofed shelters built from wood and mud. These kotas belong to Gujjar families who bring their buffaloes to pasture here in the summer months. The shepherds had already told me that the Forest Department permit rights to the pasture at Bari Dhar were held by a group of Gujjar buffalo herders that camped there during the summer months. Deso explained the arrangement that allowed him to bring his flock here:

Gujjars own the permit of this area so they can stop us using it. [But] before they arrive and after they have gone we can use these pastures without any restriction. How long shepherds stay here depends on where they are going, what other pastures they have and the general condition of the grazing. If the pasture is green we may stay a day or two longer than usual. If the pasture is less green we stay a day or two less. ${ }^{6}$

Importantly Prithu assured me they would not stay for long. By the second half of May the shepherds start to leave for their own permit pastures in upper Chamba and Lahaul.

\section{The Gujjars come to the mountain}

Groups of Gujjars began to arrive at their Dhar Khanda kotas in mid-May having spent the winter at their village homes in the valley below. Like their Gaddi neighbours, Gujjars are listed as a Scheduled Tribe; and both Gaddis and Gujjars combine transhumance pastoralism with small scale agriculture. Important differences, however, separate the two groups: Gaddis are Hindu while Gujjars practice Islam; Gaddis travel with flocks of sheep and goats while Gujjars herd buffalo. The nature of the animals they herd determines the form and extent of their respective migrations: for the Gaddi shepherds pastures such as the one at Bari Dhar are intermediary locations on their migration path -transit points on the way to and from their summer grazing areas; for the buffaloherding Gujjar such locations are a final destination. Three families (in contrast to Gaddi pastoralism it is usual for women and children to accompany men to the summer pastures) had moved up from home villages with a herd of around thirty buffaloes and a number of sheep and goats. Yusuf, the permit holder (lambardar) of the group characterised the group's migratory cycle as 'pahar ko ana-jana'-coming and going to the mountain. While Yusuf and his younger brothers Shamu and Hassan established themselves at Bari Dhar, other groups of Gujjar began to arrive at Lamba Got. Compared to the isolated homesteads of Bari Dhar, the twenty kotas at Lamba Got look like a small village. The families who visit Lamba Got in the summer bring with them over 100 buffalo and also cows, sheep and goats. They remain at Dhar Khanda until late September.

13 Yusuf described an ideal grazing pasture as having a number of features. First it must be sufficiently far from village habitation that farmers (and their grazing animals) cannot 
reach it; there should be spring water for human consumption and water holes for the animals to wallow in; and the pasture should be flat enough to allow buffalo to graze easily. All of the characteristics are found at Dhar Khanda. Additionally, Dhar Khanda is accessible and close enough to Chamba town for Gujjars to take their milk for sale in the market.

\section{Differentiating rights from access}

As stated earlier, in formal terms the Dhar Khanda meadows and surrounding forests are the property of the state and are managed by the Forest Department of Himachal Pradesh. But this statement gives only the barest flavour of the ideas of property and strategies of access that are to be found at Dhar Khanda. Moving beyond a distinction between property types as discrete entities, Dhar Khanda illustrates a reality in which resources are held in 'overlapping, and sometimes conflicting combinations of ideal property regimes' (Feeny et al. 1998: 78). Conventional debates around the dispossession of the commons tend to polarise land use as either public or private; this article shows that for these herders the reality is far more complex. Against the master categories of 'public' and 'private' property we can recognise the ability to access resources as being mutually constituted by varied constituencies of actors. State and market play a part in this but they are refracted through the lenses of contemporary society and local politics.

Property rights literature ${ }^{7}$ has tended to focus on the relative merits of private, state or common property and the forms and conditions that have ensured the long term survival and sustainability of particular examples of common resource management. But, as Agrawal points out, by concentrating attention exclusively on institutional arrangements and the rules governing resource use, common property theorists can overlook the shifting social and political-institutional environments in which access arrangements are situated (2003: 248). This leads us to Ribot and Peluso's differentiation of property from access. Here property is defined as 'the right to benefit from things' while access extends to 'the ability to derive benefits from things' (2003: 153). While Ribot and Peluso recognise property as important, it is but one of a set of factors in an array of 'institutions, social and political-economic relations, and discursive strategies' that shape benefit flows (2003: 157). Aside from property there are to be found a variety of other access mechanismstechnology, capital, markets, labour, knowledge, identities and social relations-that condition people's ability to benefit from resources (Ribot \& Peluso 2003: 159-60). Ribot and Peluso point to the ways in which different actors hold and draw upon different 'webs of relationship' and 'bundles of power' to configure resource access (2003: 154). By viewing property relations as social relationships we are able to shine a light onto the networks of power and authority that enable people to gain benefits from resources or that prevent them from doing so.

16 Applying Ribot and Peluso's framework to the examples of pasture use at Dhar Khanda allows us to map the mechanisms that determine forms of access to resources. Setting out the terms on which the above described groups of Gaddi shepherds and Gujjar herders gain access to the resources of Dhar Khanda reveals the differing ways and relevant institutions through which their practices are legitimated. Let us start with some history. A story is commonly recounted of how, a little more than a hundred years ago, having tasted fresh buffalo milk while visiting neighbouring Jammu, the Raja of Chamba invited a number of Gujjar families to settle in his state. Two brothers began to visit Dhar Khanda 
in the summer months; one brother established himself at Lamba Got and the other at Bari Dhar. The Raja formalised this arrangement when he requested that grazing tax be paid and milk brought daily to his palace. The settlement of rights in Chamba did not mean the termination of local people's ability to access resources so much as the establishment of a legal relationship between citizens and the state. Holding the grazing licence for Bari Dhar gives Yusuf's family an official right to exclusive use of the pasture. These are the 'traditional rights' ('waris') guaranteed by the Forest Department to the direct descendants of the herders who were initially invited to Dhar Khanda in the $19^{\text {th }}$ century. Thus it is firstly through what Ribot and Peluso (2003: 161) term rights-based access that the Gujjars at Dhar Khanda claim their rights to pasture. Processes of forest settlement saw traditional rights formalised into grazing permits which specified the extent of a pasture, the ways it could be used, and imposed a grazing tax on right holders. Yusuf's name is recorded on the permit which grants permission to take buffalo to the pasture at Bari Dhar. Other Gujjar families are similarly 'permitted' to graze their buffalo on Lamba Got. However, rather than the neutral enforcement of regulation, Yusuf acknowledges that the best he can hope for from the state is some form of (probably costly and always delayed) official arbitration over disputes. 'Paper rights' are not as secure as they are presented to be.

While legally recognised rights to property are important, actual access is constituted through a broader range of processes and social institutions. Ribot and Peluso's distinction between 'the right to benefit' and 'the ability to derive benefits' allows us to identify the social, political and economic relations that shape benefit flows (2003: 157). The Forest Department's official claim of ownership and the formal allocation of userights to named individuals are simply the basis from which negotiations over access proceed. Though rights of use are assigned to individuals, permit holders remain subject to a range of social obligations and group pressures that expose the simplicity of official definitions. To distinguish between institutional arrangements Cleaver employs the terms 'bureaucratic' and 'socially embedded' for, respectively, the explicit organizational structures of governments and 'culture, social organization and daily practice' (2002: 14). While processes constituting property may or may not be distinct from those constituting access, it is likely to be much harder to untangle the 'bureaucratic' from the 'socially embedded.'

Comparing the situation of Gujjar herders with that of Gaddi shepherds demonstrates the different strategies required to turn particular rights into forms of access. While many of the Saal valley shepherds do hold permits for grazing, these only cover specific locations in the upper parts of the Chamba valley, in the District of Lahaul, and in the Siwalik Hills. As Phillimore (1981: 103) points out, the Forest Department and Gaddi migratory shepherds differ in their views of what constitutes a grazing right. To the Forest Department these permits relate to particular grazing runs i.e. it is a right to a specific place. Shepherds on the other hand view a permit as giving permission to hold flocks and move between summer and winter grazing grounds i.e. it is the right to travel. Gaddi legal entitlements to the resources of Dhar Khanda are not as strong as those claimed by permit-holding Gujjars. However, the shepherds are able to reinforce their weak legal entitlements with a series of overlapping informal claims to customary rights of use. Time spent at Dhar Khanda derives from its proximity to the shepherds' home villages in the Saal valley. Villagers from this area have a long history of grazing their village-based flocks on the lower slopes of Dhar Khanda. On this basis, the Gaddi shepherds present 
claims to access the Dhar Khanda meadows that, if legally unauthorised, are socially acknowledged and supported.

As Ribot and Peluso explain, "privileged access to the individuals or institutions with the authority to make and implement laws can strongly influence who benefits from the resource in question' (2003: 170). The numerically dominant Gaddis are adept at manipulating political processes. As a relatively unified 'vote bank', the political clout of the Gaddi community provides a means to gain improvements in access to pasture resources (Saberwal 2003: 214). Additionally, in comparison with the Gujjars of Chamba District, members of the Gaddi Scheduled Tribe possess a superior record of obtaining employment within the state, including at the lower levels of the Forest Department. This was the case for Gaddis on Dhar Khanda; close to their home villages, relationships with the institutions of the state are often intimately bound up with kinship relationships. ${ }^{8}$ Thus, on the one hand, the Gujjars' official right of use is recorded in law and, in theory (if not in practice), is enforced by the institutions of the state while, on the other hand, the Gaddi shepherds' claims derive from notions of custom that are legitimised through socio-cultural norms and political brokerage. Here we can identify two distinct webs of relationships through which users organise resource access. Ideally these two systems of access are separate in terms of the timing of migration and the needs of their respective sets of animals. While buffalo graze on the flat meadows (dhar), sheep and goats venture onto the steep forested slopes (dhad or fāt) to either side. The Gaddis argue that, as their sheep and goats eat differently, their short stay will not reduce the grazing available to the Gujjars' buffalo. ${ }^{9}$ Gaddi flocks access grazing here from late April to mid-May and the Gujjars should not arrive until after they have left. Similarly, in the later part of the season the Gujjars should have gone down to their home villages by the time the Gaddi flocks return in October.

But this was not always the case on the Dhar Khanda ridge. At various times in the last decade the timings of migration have diverged from the required schedule. Furthermore, changes in the economics of nomadism-specifically the rise in the price of meat-have seen both Gaddis and Gujjars bringing an increasing number of goats to the pasture. This raises the question of what happens when two sets of customs governing access and use come into contact with one another. As Peluso and Lund point out, 'the mechanisms of land control need not always align [but may be] wielded in concert or competition with one another' (2011: 668). In situations characterised by normative pluralism and legal ambiguity, exactly who is entitled to access a particular resource, and the manner in which they do so, become highly contested. The next section presents two extended case studies that demonstrate struggles over access and clashes in the values and norms used to justify competing requirements.

\section{Access to grazing resources part 2: conflict, competition and exclusion}

\section{Tensions on the ridge}

In 2002 when I met Rustam at Lamba Got it was against a background of communal unrest. In February of that year an anti-Muslim pogrom was carried out in Gujarat as retaliation for the burning of a train carrying Hindutva activists from Ayodhya. The previous December an attack on the Indian Parliament building brought a rapid 
deterioration in relations with Pakistan. In the heat of May and June international concerns rose with the build-up of troops along the border between these two nuclear armed states. These tensions were reflected on the migration trail. Throughout the summer I witnessed frequent name-calling and occasional physical violence between Hindu shepherds and Muslim buffalo herders. From the Gaddi side there were mutterings about Gujjars sheltering terrorists and having weapons hidden in their kotas. When I returned to Dhar Khanda in late September tensions were simmering still.

Reflecting on the situation, Rustam told me that when the Gujjars had arrived at Dhar Khanda back in May the Gaddis were not ready to leave. Their refusal to move on was a direct challenge to the authority of the permit-holder's right to graze:

I have a permit from the Forest Department. It allows me to stay here for six months each year. My family has been coming here for 200 years. Before the month of May shepherds come here and stay a few days using the pasture and staying in the kotas. At that time it is too cold for buffalo to come here. The problem is when shepherds want to stay here after we have arrived. [This year] some shepherds started to graze their sheep and goats on the main [flat] meadow. If they are passing through they should use the [steep slopes of the] forest and maybe stay for one night but they were using the meadow and not passing through. They came onto the pasture because there was only one woman here and she couldn't stop them..$^{10}$

While Rustam accepted that the shepherds could use the Dhar Khanda pasture for grazing early and late in the season, many were less generous and accused the Gaddis' animals of dirtying water holes and being 'greedy for the leaves of trees [when] there is not enough here for them. ${ }^{11}$

Though the shepherds generally aim to arrive back in the Saal valley in mid-October, in 2002 a number of flocks returned early from the high pastures complaining of animal disease and a lack of adequate grazing. As the largest flock owner and one of the most senior shepherds, Dharam Chand's opinion carries a lot of weight. Though the Gujjars' permits provide them with a legally irrefutable access claim to the pasture, Dharam Chand felt able to argue a right of use on the basis of tradition:

This is a got-it is called Lamba Got-[which means that] it is a Gaddi grazing place. ${ }^{12}$ Because of the Gujjars we can't use it anymore but in my grandfather's time we used this place. Now we are forced to go down into the forest to find grazing. The Gujjars bought the permit from the Forest Department. They are supposed to use it for grazing only but now they are also growing crops here. I have made legal petitions to take back my rights but everyone says I am just an old shepherd and they give me no importance. ${ }^{13}$

Rather than being rigidly defined we see here that access can be subject to contestation even on the basis of place names and the implications these have for traditional usage. Recalling that relations between shepherds and buffalo herders had been more cordial in the past, Dharam Chand argued that recent disputes were caused by overpopulation: 'Gujjars are having too many children and so have come to overuse the pasture. They are staying here for ten or fifteen days longer now. ${ }^{14}$ Expanding on this theme Dharam Chand advanced a number of geographical, historical, demographic and political assertions. He concluded:

Since 1947 ... the granting of rights to minorities has increased. But this is Gadderan -the land of Gaddis. This we should remember. I have done this work from my childhood. My family have worked as shepherds since before memory-all our forefathers were shepherds. 
abandoned Gujjar kotas. Deso also voiced his frustrations about the situation:

Where there is good grazing Gujjars are always there before us. The problem is that the Gujjar block the way and stop us from using the pastures. They exaggerate their permit land beyond what is allowed. They stop our goats drinking the water even. Now the problem is worse than before-there are more Gujjar and more buffalo and they act like gangsters [goondas]-they steal the blankets we leave in our camps. Four or five shepherds can't fight two or three Gujjar families.

While over the last decade, a certain amount of Hindu-Muslim (and Gaddi-Gujjar) tension has manifested itself on occasion, the complaints made in 2002 were particularly vociferous. Though undoubtedly the lack of adequate grazing and water played at part, the language used ('chalo Pakistan') demonstrated a communal edge to these conflicts over resources.

\section{Access, authority and legitimacy}

This article has moved beyond the analysis of 'property' to consider broader notions of 'access'. While property may be legally recorded and recognised, processes by which access is legitimised require appeals to a range of institutional forms. Here notions of legitimacy are not fixed but rather are constantly renegotiated and refined as part of attempts to secure authority over a resource. To Sikor and Lund (2009) questions of access cannot be uncoupled from questions of authority and power. Where forms of authority co-exist, overlap and contradict one another they recommend that we investigate the processes by which claims to access and property are 'made and solidified or challenged and, possibly, undone' (2009: 6). Against a background of contested claims, the Dhar Khanda ridge is an arena within which struggles over ideas of legitimate authority are played out. As Pauline Peters points out, competition over claims takes place through competition in meanings: 'whose right, which meaning, whose definition are critical questions in deciphering changes in systems of land rights' (1987: 192). In this section we can see the ways in which the varied parameters of tenure are explained, justified and challenged by those that used to use them, currently use them or seek to use them.

29 At Dhar Khanda conflicts over resources are most obviously expressed in individual claims to long-standing customary use. A connected strategy relates a broader sense of tradition by forwarding a territorial dimension in which ethnic and religious identities, history and geography are interlinked. In both these instances custom and tradition are employed as discursive manipulations to justify resource access. The depth of the Gaddis' attachment to shepherding as a way of life is expressed by their assertion that their shepherding dharma was allocated to them by Lord Shiva ${ }^{15}$ and that Gadderan-the Gaddi homeland-is coterminous with Shiv Bhumi ${ }^{16}$ In contrast to the (relatively) newly arrived Gujjars, the Gaddis claim access to resources in ways that precede state-sanctioned rights of property. The right to graze at Dhar Khanda is thus claimed through the Gaddis' ethnic and religious identity related through notions of indigeneity. Notions of Gaddi identity and of 'Gadderan' as their imagined homeland are used to counter the Gujjars' association with the Chamba Raja and the old Chamba State.

The constitution of categories such as 'land' and 'people' demonstrates the extent to which state forms have penetrated the way we think about property and identity. As Agrawal (2005) has argued, users' interactions and relationships with their environments 
may be shaped, in informal and indirect ways, by state policies, institutional structures and official rhetoric. Elmhirst relates how the recording of traditional rights and customary laws produces what she calls 'racialized territorialisation' as the systematic classification of people gives rise to ideas of 'legitimate belongings, entitlement and territorial attachment' (2011: 174). Across the western Himalayas the settlements and censuses of the $19^{\text {th }}$ century continue to resonate in one-dimensional forms of identification-as 'Bakarwal', 'Gaddi, 'Gujjar', 'Bhotiya'-that are uniformly connected to rights over particular territories. Berry (2009) points out that attempts to clarify property rights have frequently provoked, rather than alleviated, social and political conflict. The reverse side of granting access according to notions of ethnicity and territory is that those unable to articulate their identity according to prevailing notions of belonging will find themselves excluded. This explains some of the animosity between Gaddi and Gujjar herders that was so apparent when I first arrived in Chamba.

Explanations for the tensions of 2002 require an understanding that struggles over rights do not take place within a bounded locality. The wider political situation cannot be ignored as mounting political tensions between Pakistan and India found expression in the hills and forests of Chamba District. Local struggles were influenced by and fed-into national-level politics and ideas about how people should be ordered within national (and international) space. Conflicts over the rights to pasture resources at Dhar Khanda clearly parallel broader contestations over citizenship and the right to claim place in India as a whole.

So far we have seen how access arrangements are shaped by formal systems of state sanctioned property rights but are by no means limited to them. The power to produce categories of knowledge is significant in legitimizing state authority over property. But this is not to suggest that local people are solely without agency in processes of knowledge production. Kapila (2008) has shown the Kangra Gaddi to be familiar with the language of rights and adept at deploying ideas of indigeneity and ethnic identity when making claims to Scheduled Tribe status. Similarly, Bergmann et al. (2011) describe how nomadic Bhotiyas in the Kumaon Himalaya have been able to position themselves and act effectively along webs of relationships stretching from the local to the global (2011: 107). On the meadows and in the forests of the western Himalayas, justifications of resource access intertwine in complex dynamics that merge with a wider politics of identity and geography.

If access arrangements reveal something of the everyday processes of identity formation, they also allow insights into the everyday processes of state and authority production and legitimation. Interestingly, as Sikor and Lund suggest, when authority and power relations are contested, politico-legal institutions tend to compete for authority. Already we have seen how the Gujjars appeal to a particular idea of a hierarchical bureaucratic state able to confer rights over property. Against this the Gaddis attempt to legitimate their resource use by presenting ideas of tradition that fit with recent national efforts to democratise resource management and also with the lower levels of the state in which policy is translating into the vernacular. In making these appeals resource users confer authority in different ways. In the presence of competing forums for resolving disputes, contestants tend to 'shop' for forums for dispute resolution: 'and forums actively shop for disputes in an effort to consolidate their authority' (Sikor and Lund 2009: 10). The next section presents another case in which particular claims to authority are forwarded and confirmed in disputes over the use of pasture at Dhar Khanda. 


\section{Tusli Ram's land grab}

While the arguments over resource access were particularly heated in 2002, other, less overt, conflicts have played out on the meadows of Dhar Khanda over the last decade. Here, differences did not derive from ethnic or religious identity, so much as reflect disparities in economic and political capital and the social authority that accrues to some individuals but not to others.

This paper has already outlined the ways access to Dhar Khanda pastures is negotiated by permit-holding buffalo herders and migratory shepherds with homes in nearby villages. An additional level of complexity is added by a number of flocks whose migration route follows the Dhar Khanda ridge but which are owned by shepherds who do not live locally. of this category of transiting shepherds Tulsi Ram Bharmouri owns the largest flock. A barapuhal such as Tulsi Ram requires additional labour to manage his animals. 18-year-old Virū-one of the five chotepuhal employed by Tulsi Ram-filled me in on the roles and origins of this group of shepherds:

Tulsi Ram is the permit holder [malundi]. Together with his brothers he owns most of the animals. I work for them as do my friends Sunka and Subhash. We are going to Bharmour which is Tulsi Ram's home village, but I am from this area [the Saal valley].

Jobbing shepherds like Virū (and Mohinder and Dimu who travel with Prithu and Deso) work either for cash or for the opportunity to bring their own animals under a Forest Department-issued grazing permit. In this way labour is traded for being allowed to travel under the formal protection of a grazing permit. Lacking official or customary rights to property, these 'small' shepherds (chotepuhal) gain a precarious form of resource access by working for those who have such rights.

With their home villages (and related spring / autumn grazing) at the eastern end of the Chamba valley, shepherds like Tulsi Ram acknowledged they could pass through pastures such as the one at Lamba Got only at the pleasure of the local shepherds. By agreement they moved quickly through the area at the commencement and the tail-end of the grazing season. Tulsi Ram described the arrangement as follows:

Everyone can use this got-it's on the route up to Tundah valley and the Kalichho pass so hundreds of flocks pass through each year. Going to the mountains everyone can use this pasture as there is new grass here every year. In the autumn it is harder. If someone else had been here when we arrived we would have just stayed a bit higher or a bit lower or go on further-it's not a big problem. We only stay at each place for a day or two so there is plenty of grass left for others.

Tulsi Ram confirmed that he would have to leave Lamba Got before the arrival from nearby Chaghan village of the small flock belonging to Harilal and Monnu. However, under certain circumstances, for example in return for payment or some later reciprocal arrangement, the Saal valley shepherds allowed transiting non-local flocks to stay for longer. In 2003 Tulsi Ram explained that it was acceptable for him to stay for a short time at Lamba Got while travelling to and from his own 'permit' grazing above Pulni close to Bharmour. As he pointed out, in turn, others used the Pulni pasture quite freely before and after his own stay there.

When I started my fieldwork in Chamba District, Harilal had been the oldest of the migratory shepherds whose family homes are in the villages surrounding Dhar Khanda. Together with his nephew Monnu, Harilal took a small flock of 50 animals from Punjab to 
Lahaul and back each year. The previous year Harilal and Monnu had lost over a third of their sheep and goats to disease. Even so, Harilal was adamant that he would continue migrating with the flock:

If we finish this shepherding work we will have nothing. If there is no flock then we won't be able to have meat. Society won't feed us, we won't have wool. The land on the mountain isn't fertile so farming alone isn't an option here. We can sell animals from the flock to get money when we need it. ${ }^{17}$

Returning in 2010 I learned that Harilal and Monnu had 'retired' from migratory shepherding. The family still owned a number of sheep and goats but these animals now grazed year round in the Saal valley. Piecing together the stories from a number of different sources, I heard how, over time, the large flock belonging to Tulsi Ram had outgrown his traditional permit pasture at Pulni. He had therefore decided to leave Bharmour earlier and to spend longer at other locations along the migration path. Whereas before Tulsi Ram had not tarried at Lamba Got, in 2006 he extended an overnight stay to a full week. The following year he remained for more than two weeks. Several of the Saal valley shepherds were openly critical of Tulsi Ram's attempts to extend his stay at Dhar Khanda beyond the usually accepted time. The feeling was that Harilal and Monnu had been pushed off their rightful grazing place. Tulsi Ram had little interest in these complaints and argued that the pasture was underused. He reinforced his claim to the pasture by arguing that because the shepherds he employed all came from villages in the Saal valley they therefore had a legitimate right to access grazing there.

41 If the Saal valley shepherds benefited from the overlap of local state and local society, Tulsi Ram trumped them for influence. It was known that Tulsi Ram was from a wealthy and well-connected family and his influence extended through kinship ties to a powerful politician. Unsurprisingly, there was little appetite for or prospect of directly challenging his claims to spend more time at Lamba Got. Tulsi Ram's annexation of a corner of the Lamba Dhar pasture rested on a web of relationships that spanned the economic, social and political. However dressed up, the bundle of powers available to Tulsi Ram was recognised as the ultimate form of authority: 'jiski lathi uski bhains': who has the stick has the buffalo.

\section{What happened next?}

In 2013 I walked up to Lamba Got to visit Rustam. He confirmed that tensions with migratory Gaddi shepherds had decreased. Forest Department officials had visited Dhar Khanda and had brought the conflicting parties together in an amicable compromise ( rajinama) by which the shepherds could transit the pasture so long as they promised not to trespass. ${ }^{18}$ I also learned that Deso and Yusuf had come to an agreement whereby Yusuf's son would take the family's expanding flock of goats with the Gaddi flock to Lahaul to escape the monsoon rains. Shepherds liked to emphasise how normally restrictive social norms are considerably loosened while migrating: 'at the high pastures these things [ethnic and caste distinctions] are less important-everyone eats from the same plate. ${ }^{19}$

The same year I took the opportunity to see Harilal at his village house. When I reminded him of his earlier intention to work until he died, he replied: 'I would have liked to keep visiting Lahaul but I don't get to decide these things. ${ }^{20}$ 

resources of the Dhar Khanda ridge can be gained. Concentrating on the changing access arrangements of a single area of pasture over the course of a decade allows us to see the circumstances in which individual and shared interests align, combine, separate and clash. Dhar Khanda can be seen as a 'grey space' on which ideas of property and access, and authority and power, are negotiated and tested. Stakeholders draw upon different bundles of powers and webs of relationships to configure resource access. Residence, family, caste, custom, tradition, ethnicity and religion are all deployed in attempts to bolster a continuum of claims ranging from the individual to the collective. Resulting configurations vary in temporal terms (across days, weeks, months, seasons, and years), depend on social settings (the relationships of different groups and individuals) and relate to wider political and economic contexts (changes in the respective roles and reach of the state and the market). At times groups of users coalesce around common interests. At others times identities harden and borders are thrown up. Constellations of social norms, kinship relations, economic calculus and political power come together in ways that promote access for some but deny it to others. of efficiency and sustainability but less to the question of equity. Negotiations and contestation over access take place within hierarchies of varied users. Examining who is able to negotiate access and how they do so highlights processes of inclusion and exclusion. In the Dhar Khanda case there has been a clearly obvious division between the Muslim Gujjars and the Hindu Gaddis. As climatic variation and economic incentives interact with wider political events, the friction between these two groups may flare up into conflict. However, given the longstanding cooperation between some members of these two communities and the complementarities of their respective activities, flashpoints usually prove short-lived; tensions dissipate into a new working equilibrium. Though often submerged beneath combative rhetoric around race and religion, this article also points to processes of differentiation within and between groups of Gaddi 
shepherds. The changing economics of pastoral production have widened differences between wealthy permit-holding barapuhals and labouring chotapuhals. Those with larger flocks are able to utilise their wealth and power to dispossess others who forward claims to access that depend on traditional use or state sanctioned rights. Ongoing changes in state and market are likely to exacerbate these trends.

These examples from the Dhar Khanda ridge present an alternative perspective on narratives of state efforts to restrict and regulate forest use. The cases presented here suggest dynamic relationships exist between resource users and various form of social and legal authority. Alongside state regulation of forest resources, other smaller, but no less significant, processes of enclosure, accumulation, dispossession and expulsion are taking place. And within these processes we can see how particular political visions of the 'correct' relationship between identity and territory are being legitimised.

\section{BIBLIOGRAPHY}

Agrawal, Arun (1999) Greener Pastures: Politics, Markets and Community among a Migrant Pastoral People, Durham (North Carolina): Duke University Press.

Agrawal, Arun (2003) 'Sustainable Governance of Common-Pool Resources: Context, Methods, and Politics', Annual Review of Anthropology, 32, pp. 243-62.

Agrawal, Arun (2005) Envronmentality: Technologies of Government and the Making of Subjects, Durham (North Carolina): Duke University Press.

Axelby, Richard (2005) Pastures New: Pastoral Development and the Determination of Grazing Access in the Indian Himalayas (Unpublished doctoral dissertation), University of London.

Axelby, Richard (2007) “'It Takes Two Hands to Clap”: How Gaddi Shepherds in the Indian Himalayas Negotiate Access to Grazing', Journal of Agrarian Change, 7(1), pp. 35-75.J17B.

Baland, Jean-Marie; Platteau, Jean Philippe (1996) Halting Degradation of Natural Resources: Is There a Role for Rural Communities?, Oxford: Clarendon Press.

Bergmann, Christoph; Gerwin, Martin; Sax, William S.; Nüsser, Marcus (2011) 'Politics of Scale in a High Mountain Border Region: Being Mobile among the Bhotiyas of the Kumaon Himalaya, India', Nomadic Peoples, 15(2), pp. 104-29.

Berry, Sara (2009) 'Property, Authority and Citizenship: Land Claims, Politics and the Dynamics of Social Division in West Africa', Development and Change, 40(1), pp. 23-45.

Bhattacharya, Neeladri (1986) ‘Colonial State and Agrarian Society’, in Sabyasachi Bhattacharya \& Romila Thapar (eds.), Situating Indian History, Delhi: Oxford University Press, pp. 171-94.

Bhattacharya, Neeladri (1995) 'Pastoralists in a Colonial World', in David Arnold \& Ramachandra Guha (eds.), Nature, Culture, Imperialism, Delhi: Oxford University Press, pp. 49-85.

Chakravarty-Kaul, Minoti (1996) Common Lands and Customary Law: Institutional Change in North India over the Past Two Centuries, Delhi: Oxford University Press. 
Chakravarty-Kaul, Minoti (1997) 'Transhumance: A Pastoral Response to Risk and Uncertainty in the Himalayas', Nomadic Peoples, 1(1), pp. 133-49.

Cleaver, Frances (2002) 'Reinventing Institutions: Bricolage and the Social Embeddedness of Natural Resource Management', The European Journal of Development Research, 14(2), pp. 11-30.

Dangwal, Dhirendra Datt (2009) 'The Lost Mobility: Pastoralism and Modernity in Uttarakhand Himalaya (India)', Nomadic Peoples, 13(2), pp. 84-101.

Elmhirst, Rebecca (2011) 'Migrant Pathways to Resource Access in Lampung's Political Forest: Gender, Citizenship and Creative Conjugality', Geoforum, 42(2), pp. 173-83.

Feeny, David; Berkes, Fikret; McCay, Bonnie J.; Acheson, James M. (1998) 'The Tragedy of the Commons: Twenty-Two Years Later', in John Baden \& Douglas S. Noonan (eds.), Managing the Commons, Bloomington: Indiana University Press, pp. 76-94.

Gooch, Pernille (2004) 'Van Gujjar: The Persistent Forest Pastoralists', Nomadic Peoples, 8(2), pp. 125-35.

Irfanullah, Sahibzada (2002) 'Gujars in the Pakistani Hindu Kush Himalayas: Conflicts and Dilemmas about Lifestyles and Forest Use', Nomadic Peoples, 6(2), pp. 99-109.

Kapila, Kriti (2008) 'The Measure of a Tribe: The Cultural Politics of Constitutional Reclassification in North India', Journal of the Royal Anthropological Institute, 14(1), pp. 117-34.

Noble, Christina, (1987) Over the High Passes: A Year in the Himalayas with the Migratory Gaddi Shepherds, London: Collins.

Ostrom, Elinor (1990) Governing the Commons: The Evolution of Institutions for Collective Action, Cambridge: Cambridge University Press.

Ostrom, Elinor; Dietz, Thomas; Dolsak, Nives; Stern, Paul C.; Stonich, Susan; Weber, Elke K. (eds.) (2002) The Drama of the Commons, Washington: National Academy Press.

Peulso, Nancy; Lund, Christian (2011), 'New Frontiers of Land Control: Introduction', Journal of Peasant Studies, 38(4), pp. 667-81.

Peters, Pauline (1987) 'Embedded Systems and Rooted Models: The Grazing Lands of Botswana and the Commons Debate', in Bonnie McCay \& James M. Acheson (eds.), The Question of the Commons, Tucson (Arizona): The University of Arizona Press, pp. 171-94.

Phillimore, Peter (1981) Migratory Graziers and their Flocks: A Royal Geographical Society Expedition Report, London: Library of the Royal Geographical Society.

Rao, Aparna (2002) 'Pastoral Nomads, the State and a National Park: The Case of Dachigam, Kashmir', Nomadic Peoples, 6(2), pp. 72-98.

Ribot, Jesse; Peluso, Nancy Lee (2003) 'A Theory of Access', Rural Sociology 68(2), pp. 153-81.

Saberwal, Vasant K. (1999) Pastoral Politics: Shepherds, Bureaucrats and Conservation in the Western Himalaya, Delhi: Oxford University Press.

Saberwal, Vasant K. (2003) 'Policy, Property, and Access: Shepherd Land-Use in the Western Himalayas', in Aparna Rao \& Michael J. Casimir (eds.), Nomadism in South Asia, Oxford: Oxford University Press, pp. 212-46.

Sandford, Stephen (1983) Management of Pastoral Development in the Third World, Chichester: John Wiley and Sons.

Scoones, Ian (ed.) (1995), Living with Uncertainty: New Directions in Pastoral Development in Africa, London: Intermediate Technology Publications Ltd. 
Sharma, Mahesh (2012) 'State, Pastures and Rice-Fields: The Gaddi Shepherds of Himachal Himalayas (North India)', Man in India, 92(1), pp. 13-35.

Sikor, Thomas; Lund, Christian (2011) ‘Access and Property: A Question of Power and Authority', Development and Change, 40(1), pp. 1-22.

Singh, Chetan (1998) Natural Premises: Ecology and Peasant Life in the Western Himalaya 1800-1950, Delhi: Oxford University Press.

Singh, Chetan (2009) 'Pastoralism and the Making of Colonial Modernity in Kulu 1850-1952', Nomadic Peoples, 13(2), pp. 65-83.

Vasan, Sudha (2002) 'Ethnography of the Forest Guard: Contrasting Discourses, Conflicting Roles and Policy Implementation', Economic and Political Weekly, 5 October, pp. 4125-34.

\section{NOTES}

1. I am grateful to the following people for reading versions of this paper and providing helpful advice and comments: Professor Peter Molinga, Dr. Saurabh Gupta, Professor Jonathan Parry, Dr. Bengt Karlsson, Dr. Jens Lerche, Dr. Alpa Shah, Professor Katy Gardner and Professor Eva Gerharz.

2. On Bakarwal shepherds in Kashmir see Rao 2002; for the Gaddi shepherds of Himachal Pradesh see Saberwal 1999, Axelby 2007, Sharma 2012; literature on Gujjars includes Gooch 2004, Irfanullah 2002, Dangwal 2009.

3. Pseudonyms for people and local places are used throughout.

4. Deso, interview by author, Dhar Khanda, 7 November 2002.

5. See Axelby 2007 for a detailed account of the full migration route.

6. Deso, interview by author, Dhar Khanda, 19 October 2002.

7. e.g. Ostrom 1990; Baland and Platteau 1996; Ostrom et al 2002.

8. Sudha Vasan's (2002) ethnography of forest guards in Himachal Pradesh details the social influences that work upon the lower levels of officialdom.

9. Sheep nibble grass; goats range widely and consume young shoots and the leaves of lowhanging branches; buffalo need to be supplied daily with leafy branches cut from trees.

10. Rustam, interview by author, Dhar Khanda , 31 July 2002.

11. Rustam, interview by author, Dhar Khanda, 31 July 2002.

12. Gujjar grazing pastures are called dhar.

13. Dharam Chand, interview by author, Lamba Got, 21 October 2002.

14. Dharam Chand, interview by author, Lamba Got, 21 October 2002.

15. Noble 1987: 21.

16. Gadderan may refer to the Gaddi heartland in the upper part of the Chamba valley (around Bharmour and the Mani Mahesh Kailash massif), but on occasion expands to encompass the entire Chamba valley and a significant part of neighbouring Kangra District.

17. Harilal, interview by author, Chaghan village, 3 April 2002.

18. Rustam, interview by author, Dhar Khanda, 2 August 2013. See Axelby (2007) for more on this kind of informal agreement between Forest Department officials and resource users.

19. Harilal, interview by author, Chagan village, 3 April 2002.

20. Harilal, interview by author, Chagan village, 30 July 2013.

21. Viru, interview by author, Kiri Village, 18 October 2002. 


\section{ABSTRACTS}

Based on ethnographic fieldwork conducted over a period of ten years this article details the access arrangements that govern the use of a grazing pasture in Chamba District of Himachal Pradesh, India. Following Ribot and Peluso's (2003) distinction between 'property' and 'access' I explore the area between that which people have property rights to, and that which they are able to extract benefit from. In parallel to this Sikor and Lund (2009) identify a second 'grey zone' existing between authority and power where decisions about how resources are distributed in society are legitimised. Taking as its subject the multiple ways that these two sets of relationships play out, this article considers the everyday politics through which Gaddi shepherds and Gujjar buffalo herders activate and justify their presence on the pasture. Examining the politics of natural resource use in this way brings to the fore inequalities in access and explains the ways in which they occur.

\section{INDEX}

Keywords: common property, resource access, inequality, nomadism, Himalayas

\section{AUTHOR}

\section{RICHARD AXELBY}

Postdoctoral Research Fellow, Inequality and Poverty Research Program, Department of Anthropology, London School of Economics. (Funded by the ESRC and the EU, Principal Investigator: Alpa Shah). 